\title{
Pemodelan Regresi Spline pada Studi Kasus Angka Kematian Bayi di Jawa Timur Tahun 2015
}

\author{
Maria Fatima O L ${ }^{(1)}$, Wara Pramesti (2) \\ ${ }^{1,2)}$ Universitas PGRI Adi Buana Surabaya \\ J1. Dukuh Menanggal XII Telp./Fax. (031) 822289873 Surabaya 60234 \\ e-mail: riatyladjar2014@gmail.com dan estipra72@gmail.com
}

\begin{abstract}
ABSTRAK
Persoalan yang dihadapi Provinsi Jawa Timur dalam bidang kesehatan adalah angka kematian ibu (AKI) dan angka kematian bayi (AKB) yang mengalami penurunan secara lambat. Berkaitan dengan target Millenium Development Goals (MDGs) tahun 2015 untuk AKB adalah 23 kematian per 1.000 kelahiran hidup. AKB di Provinsi Jawa Timur menurut Badan Pusat Statistik (BPS) pada tahun 2015 yakni sebesar 24 kematian per 1.000 kelahiran hidup. Berdasarkan tingginya AKB di Jawa Timur tahun 2015 maka metode regresi spline diterapkan untuk mengkaji AKB dan faktor-faktor yang mempengaruhinya. Dari hasil analisis didapatkan bahwa model spline linear hubungan antara persentase persalinan oleh tenaga non medis terhadap angka kematian bayi di Jawa Timur tahun 2015 dengan satu titik knot berdasarkan Generalized Cross Validation (GCV) minimum sebesar 39,22079. Berdasarkan hasil analisis juga didapatkan model spline linear multivariabel terbaik adalah spline linear dengan satu titik knot berdasarkan Generalized Cross Validation (GCV) minimum sebesar 34,11737. Variabel yang berpengaruh signifikan tehadap angka kematian bayi di Jawa Timur tahun 2015 adalah : persentase perempuan yang usia perkawinan pertama kurang dari 17 tahun dan persentase wanita yang tidak pernah sekolah/tidak tamat SD.
\end{abstract}

Kata kunci : Angka Kematian Bayi, Generalized Cross Validation, Regresi Spilne.

\section{ABSTRACT}

The question facing the East Java province in the field of health is maternal mortality (AKI) and infant mortality $(A K B)$ which has decreased slowly. With regard to the target of the Millennium Development Goals (MDGs) in 2015 to AKB is the 23 deaths per 1.000 live births. AKB in East Java province, according to the Central Bureau of statistics (BPS) in 2015 i.e. amounting to 24 deaths per 1.000 live births. Based on the high degree of $A K B$ in East Java the year 2015 then regression splines method applied to analyze AKB and the factors that affected it. Analysis of the results obtained that the linear relationship between the precise model of the percentage of labor by non medical personnel against infant mortality in East Java the year 2015 with 1 point of knots based on Generalized Cross Validation (GCV) a minimum of 39.22079. Based on the results of the analysis also obtained the best model Multivariable linear splines are linear splines with 1 point of knots based on Generalized Cross Validation (GCV) a minimum of 34.11737. Variables that influence significantly taking action against infant mortality in East Java the year 2015 are: the percentage of women who are the age of the first marriage of less than 17 years and the percentage of women who never school/did not finish ELEMENTARY SCHOOL.

\section{Keywords : General Cross Validation, Infant Mortality Rate, Spline Regression.}

\section{PENDAHULUAN}

Spline merupakan potongan polinomial (piecewise polynomial), yaitu polynomial yang memiliki sifat tersegmen yang kontinu. Sifat ini yang memberikan fleksibilitas lebih daripada polinomial biasa, sehingga memungkinkan untuk menyesuaikan diri secara efektif terhadap karakteristik lokal dari fungsi atau data (Euba, 1999).
Regresi spline adalah model regresi dengan kurva regresinya (fungsi regresinya) berupa fungsi spline. Metode spline ini sangat baik dalam memodelkan data yang polanya berubah-ubah pada sub interval tertentu. Estimasi kurva regresi nonparametrik spline dapat dilakukan dengan mencari model spline optimal yang diperoleh dengan memilih titik knot optimal. Titik knot merupakan suatu titik fokus 
dalam fungsi spline, sehingga kurva yang dibentuk tersegmen pada titik-titik tersebut. Metode yang digunakan untuk memperoleh titik knot optimal adalah metode Generalized Cross Validation (GCV) (Euba, 1999).

Salah satu persoalan yang sedang dihadapi oleh Provinsi Jawa Timur dalam bidang kesehatan adalah angka kematian ibu (AKI) dan angka kematian bayi (AKB) yang mengalami penurunan secara lambat. Berkaitan dengan kesepakatan global dalam Target Millenium Development Goals (MDGs) tahun 2015, bahwasanya salah satu tujuan pokok dalam MDGs tersebut adalah menurunkan AKB hingga 23 kematian per 1.000 kelahiran hidup pada tahun 2015. Sedangkan berdasarkan catatan Menteri Kesehatan Republik Indonesia pada tahun 2015 AKB di Indonesia mencapai 34, artinya ada sekitar 34 kematian setiap 1.000 bayi yang lahir. Salah satu provinsi di Indonesia dengan AKB yang belum memenuhi target MDGs tahun 2015 adalah Jawa Timur. Tren AKB di Provinsi Jawa Timur menurut Badan Pusat Statistik (BPS) dari tahun 2012 hingga 2015 mengalami penurunan yang lambat yakni sebesar 25,5, 25, 24,5, 24 kematian bayi per 1.000 kelahiran hidup.

AKB merupakan salah satu tolak ukur untuk menilai sejauh mana ketercapaian kesejahteraan rakyat sebagai hasil dari pelaksanaan pembangunan bidang kesehatan (Pudiastuti, 2011). Berdasarkan pada tingginya AKB di Jawa Timur Tahun 2015, yaitu sebesar 24 kematian per 1.000 kelahiran hidup, maka dalam penelitian ini mengangkat studi kasus AKB di Jawa Timur tahun 2015. Penelitian berkaitan dengan kematian bayi di Indonesia sudah banyak dilakukan, namun yang mengkaji AKB dan faktor-faktor yang mempengaruhinya dengan metode spline masih terbatas. Dengan demikian, metode spline diterapkan pada studi kasus AKB di Jawa Timur tahun 2015. Metode spline mempunyai keunggulan dalam mengatasi pola data yang menunjukkan naik atau turun yang tajam dengan bantuan titik-titik knot, serta kurva yang dihasilkan relatif mulus. Spline mempunyai kemampuan yang sangat baik untuk digeneralisasikan pada pemodelan statistika yang kompleks dan rumit, maka berdasarkan hal-hal di atas, akan dilakukan pemodelan untuk Angka Kematian Bayi Di Jawa Timur Tahun 2015. Tujuan dari penelitian ini adalah untuk mendapatkan pemodelan regresi spline univariabel dan multivariabel pada studi kasus faktor-faktor yang mempengaruhi angka kematian bayi di Jawa Timur Tahun 2015.

\section{METODE PENELITIAN}

Data yang digunakan dalam penelitian ini adalah data sekunder yang diperoleh dari Badan
Pusat Statistik (BPS) Provinsi Jawa Timur. Unit penelitian yang diamati adalah masing-masing kabupaten/kota di Provinsi Jawa Timur pada tahun 2015. Provinsi Jawa Timur sendiri terdiri dari 38 kabupaten/kota.

Variabel yang digunakan dalam penelitian ini terbagi menjadi 2 (dua) yaitu variabel $Y$ (dependen) dan variabel $X$ (independen). Variabel dependen pada penelitian ini adalah angka kematian bayi di 38 kabupaten/kota di Provinsi Jawa Timur. Variabel independen yang digunakan adalah persentase perempuan yang usia perkawinan pertama kurang dari $17\left(X_{1}\right)$, persentase wanita yang tidak pernah sekolah/tidak tamat $\mathrm{SD}\left(X_{2}\right)$, persentase persalinan menggunakan tenaga non medis $\left(X_{3}\right)$ dan persentase penduduk miskin $\left(X_{4}\right)$.

Adapun langkah-langkah analisis adalah sebagai berikut:

a. Mendeskripsikan karakteristik angka kematian bayi di Jawa Timur tahun 2015.

b. Membuat scatterplot antara angka kematian bayi di Jawa Timur dengan masing-masing variabel independen $\left(X_{1}-X_{4}\right)$.

c. Memodelkan angka kematian bayi di Jawa Timur dengan menggunakan spline linear univariabel dengan 1,2, dan 3 titik knot..

d. Memilih titik knot optimal berdasarkan GCV minimum pada pemodelan spline linear univariabel .

e. Membuat pemodelan spline linear multivariabel dengan 1,2, dan 3 berdasarkan titik knot optimal dari model spline univariabel.

f. Mendapatkan model regresi spline multivariabel terbaik dengan titik knot optimal pada pemodelan spline multivariabel.

g. Memodelkan angka kematian bayi dengan variabel-variabel independennya menggunakan spline dengan titik knot optimal.

h. Melakukan pengujian signifikansi parameter dan pengujian asumsi residual dari model spline linear multivariabel terbaik.

i. Membuat kesimpulan

\section{HASIL DAN PEMBAHASAN}

3.1 Karakteristik Angka Kematian Bayi di Jawa Timur Tahun 2015

Penelitian ini menggunakan 4 variabel independen yang diduga mempengaruhi jumlah kematian bayi di Jawa Timur Tahun 2015. Statistika deskriptif dari angka kematian bayi dan 4 (empat) variabel independen tersebut disajikan pada Tabel 1. Berdasarkan Tabel tersebut dapat diketahui bahwa rata-rata AKB (Y) di Jawa Timur Tahun 2015 
adalah 28,85 , artinya terdapat 28 kematian bayi setiap 1.000 kelahiran hidup, dengan standar deviasi sebesar 11,3693. Angka kematian bayi tertinggi pada tahun 2015 adalah sebesar 56,240 per 1.000 kelahiran hidup dan yang paling rendah adalah 16,050 per 1.000 kelahiran hidup.

Tabel 1. Statistika Deskriptif Variabel Penelitian

\begin{tabular}{|l|r|r|r|r|}
\hline Variabel & Mean & Minimal & Maksimal & $\begin{array}{r}\text { Standar } \\
\text { Deviasi }\end{array}$ \\
\hline $\mathrm{Y}$ & 28,850 & 16,050 & 56,240 & 11,3693 \\
\hline $\mathrm{X}_{1}$ & 8,444 & 1,600 & 23,620 & 5,7715 \\
\hline $\mathrm{X}_{2}$ & 25,450 & 6,460 & 54,960 & 11,6309 \\
\hline $\mathrm{X}_{3}$ & 3,556 & 0,000 & 30,870 & 6,7749 \\
\hline $\mathrm{X}_{4}$ & 12,165 & 4,600 & 25,690 & 5,0341 \\
\hline
\end{tabular}

Tabel 1 dapat diketahui bahwa rata-rata AKB (Y) di Jawa Timur Tahun 2015 adalah 28,85, artinya terdapat 28 kematian bayi setiap 1.000 kelahiran hidup, dengan standar deviasi sebesar 11,3693. Angka kematian bayi tertinggi pada tahun 2015 adalah sebesar 56,240 per 1.000 kelahiran hidup dan yang paling rendah adalah 16,050 per 1.000 kelahiran hidup. Dari beberapa variabel independen yang memiliki rata-rata paling besar adalah variabel persentase wanita yang tidak pernah sekolah atau tidak tamat SD $\left(\mathrm{X}_{2}\right)$ sebesar $25,450 \%$ dengan nilai standar deviasi sebesar 11,6309. Persentase wanita di Jawa Timur yang tidak tamat SD tertinggi adalah sebesar 54,960\% dan yang terendah adalah sebesar $6,460 \%$. Berikut disajikan peta persebaran karakteristik AKB di Jawa Timur Tahun 2015 berdasarkan Kabupaten/Kota pada Gambar 1

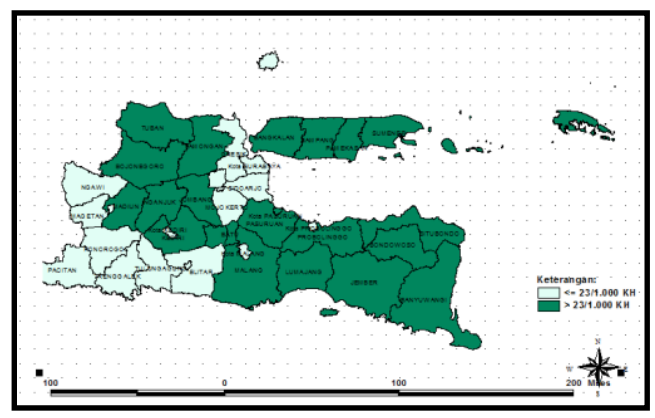

Gambar 1 Peta Persebaran AKB di Jawa Timur Tahun 2015

Gambar 1 dapat diketahui bahwa pola penyebaran angka kematian bayi di Jawa Timur tahun 2015, warna lokasi yang semakin gelap mengindikasikan semakin tinggi angka kematian bayi di lokasi tersebut. AKB diatas 23 per 1.000 kelahiran hidup dikatakan tinggi karena nilai tersebut lebih besar dari target MDGs tahun 2015 terkait indikator penurunan AKB hingga 23 per 1.000 kelahiran hidup. Jumlah Kabupaten/Kota yang memiliki AKB di atas 23 per 1.000 kelahiran hidup adalah 21 Kabupaten/Kota atau lebih dari $50 \%$ jumlah kabupaten/kota di Jawa Timur. AKB tertinggi di Kabupaten Probolinggo yang mencapai 56,24 per 1.000 kelahiran hidup dan Kabupaten Jember dengan AKB mencapai 50,2 per 1.000 kelahiran hidup. Sedangkan pola penyebaran angka kematian bayi dengan warna lokasi yang semakin terang mengidentifikasikan semakin rendah angka kematian bayi di lokasi tersebut. Terlihat bahwa Kabupaten/Kota dengan kategori AKB terletak antara 0 hingga 23 kematian per 1.000 kelahiran hidup. Terdapat 17 Kabupaten/Kota dengan AKB yang memenuhi target MDGs. Kabupaten/Kota yang memiliki AKB terendah adalah Kabupaten Trenggalek yakni sebesar 18,28 per 1.000 kelahiran hidup dan Kota Blitar sebesar 16,05 per 1.000 kelahiran hidup.

\subsection{Model Spline Univariabel}

Pada tahap pembahasan akan disajikan model spline univariabel angka kematian bayi dengan empat variabel independen yang digunakan. Sebelum dianalisis menggunakan analisis regresi spline, diselidiki dahulu pola hubungan antara masing-masing variabel dependen dengan variabel independen dengan menggunakan scaterplot.
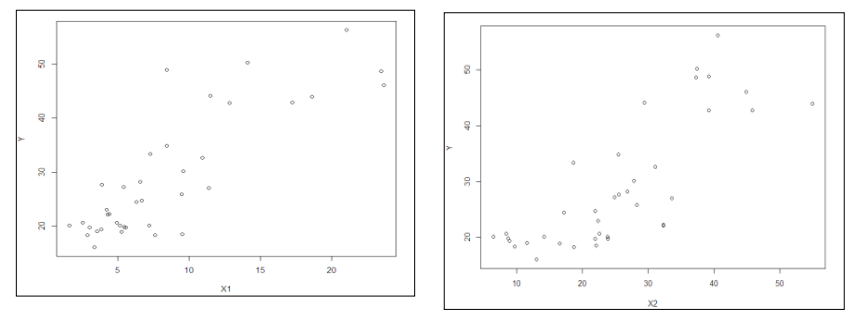

Gambar 2 (a) Plot antara Variabel AKB dengan persentase perempuan yang usia perkawinan pertama kurang dari 17 tahun. (b) Plot antara variabel AKB dengan persentase Wanita yang Tidak Pernah Sekolah/Tidak Tamat SD.

Secara visual menunjukkan bahwa ada indikasi perubahan pola perilaku dari variabel persentase perempuan yang usia perkawinan pertama kurang dari 17 tahun pada sub-sub interval tertentu. Dan pada persentase wanita yang tidak sekolah data cukup menyebar dan tidak menunjukkan ada kecenderungan membentuk pola tertentu se-hingga menyebabkan persebaran sebagian data tidak mengikuti pola tertentu. Jadi, sebaiknya data tersebut dianalisis dengan menggunakan regresi nonparametrik. Salah satu metode regresi nonparametrik yang biasa digunakan adalah regresi spline. 
J Statistika Vol. 11, No. 2,(2018), Hal. 9-16

Untuk mencari lokasi titik knot yang optimum dengan menggunakan metode GCV. Titik knot $(K)$ optimum yang yang bersesuaian dengan nilai GCV (K) minimum untuk model spline linear dengan satu, dua dan tiga titik knot pada variabel AKB dengan persentase perempuan yang usia perkawinan pertama kurang dari 17 tahun. Setelah diperoleh titik knot optimal dari model spline linear satu knot, dua knot dan tiga knot, maka perlu dipilih model terbaik. Model spline terbaik diperoleh dari nilai GCV minimum. Tabel 2 menyajikan nilai GCV dari berbagai model spline linear dan berbagai titik knot.

Tabel 2 Nilai GCV Minimum dari 3 Model Spline Linear $\left(\mathrm{X}_{1}\right)$

\begin{tabular}{|c|c|c|c|c|}
\hline \multirow{2}{*}{$\begin{array}{c}\text { Jumlah } \\
\text { Knot }\end{array}$} & \multicolumn{3}{|c|}{ Letak Titik Knot } & Nilai \\
\cline { 2 - 4 } & 1 & 2 & 3 & $\begin{array}{c}\text { GCV (K) } \\
\text { Optimal }\end{array}$ \\
\hline 1 & 22,8860 & - & - & 39,44360 \\
\hline 2 & $\mathbf{1 1 , 1 4 2 0}$ & $\mathbf{1 1 , 8 7 6 0}$ & - & $\mathbf{3 8 , 8 1 6 6 4}$ \\
\hline 3 & 10,4080 & 11,1420 & 11,8760 & 41,00189 \\
\hline
\end{tabular}

Tabel 3.2 nilai titik knot optimal yang dilihat dari GCV minimum titik knot pada model spline linear dengan dua titik knot, yakni $K_{1}=11,1420$ dan $K_{2}=$ 11,8760. Dengan demikian, model spline terbaik untuk data $\mathrm{AKB}$ dengan persentase perempuan yang usia perkawinan pertama kurang dari 17 tahun adalah model spline linear dengan 2 titik knot. Dari hasil pengujian signifikansi secara serentak diperoleh p-value sebesar 1,96 x $10^{-10}<\alpha=5 \%$ sehingga dapat disimpulkan bahwa paling sedikit ada satu parameter model yang tidak sama dengan nol. Pengujian signifikansi secara individu dapat dilihat pada Tabel 3

Tabel 3 Nilai thitung dan P-value untuk Model Spline Univariabel $\left(\mathrm{X}_{1}\right)$

\begin{tabular}{|c|c|r|r|}
\hline No & Parameter & thitung & P-value \\
\hline 1 & $\hat{\beta}_{0}$ & 5.485 & $4,02 \times 10-6^{*}$ \\
\hline 2 & $\hat{\beta}_{1}$ & 3.353 & $0,00197 *$ \\
\hline 3 & $\lambda_{1}\left(X_{1}-K_{1}\right)$ & 2.265 & $0,03002 *$ \\
\hline 4 & $\lambda_{2}\left(X_{1}-K_{2}\right)$ & -2.370 & $0,02361 *$ \\
\hline & *Signifikan pada $\alpha=5 \%$ \\
& *tabel $=2,0322$
\end{tabular}

Dengan $t_{\text {tabel }}$ sebesar 2,0322 dan menggunakan tingkat signifikansi 5\% diperoleh hasil bahwa semua parameter dalam model signifikan. Maka, Model spline linear 2 titik knot diberikan oleh persamaan :

$$
\begin{gathered}
\hat{f}\left(x_{1}\right)=15,361+1,472 x_{1}+16,369\left(x_{1}-11,142\right)_{+} \\
-17,485\left(x_{1}-11,876\right)_{+} \\
\quad=\left\{\begin{aligned}
15,361+1,472 x_{1}, & x_{1}<11,142 \\
-167,0223+17,841 x_{1}, & 11,142 \leq x_{1}<11,876 \\
40,6295+0,356 x_{1}, & x_{1} \geq 11,876
\end{aligned}\right.
\end{gathered}
$$

www.unipasby.ac.id

Tabel 3.5 menyajikan nilai GCV dari berbagai model spline linear dan 1,2, dan 3 titik knot. nilai titik knot optimal yang dilihat dari GCV minimum titik knot pada model spline linear dengan dua titik knot, yakni $K_{1}=35,5606$ dan $K_{2}=37,1773$. Dengan demikian, model spline terbaik untuk data AKB dengan persentase wanita yang tidak pernah sekolah/tidak tamat SD adalah model spline linear dengan 2 titik knot. Selanjutnya dilakukan pengujian signifikansi parameter secara simultan dan individu. Dari hasil pengujian signifikansi secara serentak diperoleh p-value sebesar 2,497 x $10^{-12}<\alpha$ $=5 \%$.

\begin{tabular}{|c|c|c|c|c|}
\hline \multirow{2}{*}{$\begin{array}{c}\text { Jumlah } \\
\text { Knot } \\
(\mathrm{K}) \\
\end{array}$} & \multicolumn{3}{|c|}{ Letak Titik Knot } & \multirow{2}{*}{$\begin{array}{c}\text { Nilai } \\
\text { GCV (K) } \\
\text { Optimal }\end{array}$} \\
\hline & 1 & 2 & 3 & \\
\hline 1 & 22,6270 & - & - & 48,34704 \\
\hline 2 & 35,5606 & 37,1773 & - & 29,97103 \\
\hline 3 & 32,3272 & 33,9439 & 35,5606 & 31,60085 \\
\hline
\end{tabular}

Tabel 4 Nilai GCV Minimum dari 3 Model Spline Linear $\left(\mathrm{X}_{2}\right)$

Sedangkan pengujian signifikansi secara individu dapat dilihat pada Tabel 5. Dengan $t_{\text {tabel }}$ sebesar 2,0322 dan menggunakan tingkat signifikansi 5\% diperoleh hasil bahwa semua parameter dalam model signifikan. Selanjutnya dilakukan uji asumsi residual identik, independen dan normalitas.

Tabel 5 Nilai thitung dan P-value untuk Model Spline Univariabel $\left(\mathrm{X}_{2}\right)$

\begin{tabular}{|c|c|c|c|}
\hline No & Parameter & $t_{\text {hitung }}$ & P-value \\
\hline 1 & $\hat{\beta}_{0}$ & 5,524 & $3,58 \times 10-6^{*}$ \\
\hline 2 & $\hat{\beta}_{1}$ & 3,560 & $0,00112^{*}$ \\
\hline 3 & $\lambda_{1}\left(X_{2}-K_{1}\right)$ & 5,540 & $3,41 \times 10-6^{*}$ \\
\hline 4 & $\lambda_{2}\left(X_{2}-K_{2}\right)$ & $-5,586$ & $2,97 \times 10-6 *$ \\
\hline
\end{tabular}

Maka, model spline linear 2 titik knot diberikan oleh persamaan :

$$
\begin{aligned}
& \hat{f}\left(x_{2}\right)=14,9010+0,4298 x_{2}+11,3766\left(x_{2}-35,5606\right)_{+}- \\
& 12,1576\left(x_{2}-37,1773\right)_{+} \\
& 14,901+0,4298 x_{2}, x_{2}<35,5606 \\
& =\left\{\begin{array}{cl}
-389,6577+11,8064 x_{2}, & 35,5606 \leq x_{2}<35,1773 \\
62,3290-0,3512 x_{2}, & x_{2} \geq 35,1773
\end{array}\right.
\end{aligned}
$$

Tabel berikut menyajikan nilai GCV dari berbagai model spline linear dan berbagai titik knot.

Tabel 6 Nilai GCV Minimum dari 3 Model Spline Linear $\left(\mathrm{X}_{3}\right)$

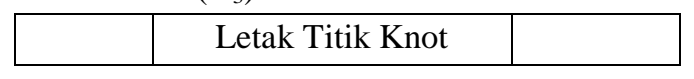


J Statistika Vol. 11, No. 2,(2018), Hal. 9-16

\begin{tabular}{|c|c|c|c|c|}
\cline { 1 - 1 } $\begin{array}{c}\text { Jumlah } \\
\text { Knot } \\
(\mathrm{K})\end{array}$ & 1 & 2 & 3 & $\begin{array}{c}\text { Nilai } \\
\text { GCV (K) } \\
\text { Optimal }\end{array}$ \\
\hline 1 & $\mathbf{7 , 2 0 3}$ & - & - & $\mathbf{3 9 , 2 2 0 7 9}$ \\
\hline 2 & 4,116 & 5,145 & - & 40,12950 \\
\hline 3 & 5,145 & 6,174 & 7,203 & 40,62211 \\
\hline
\end{tabular}

nilai titik knot optimal yang dilihat dari GCV minimum titik knot pada model spline linear dengan satu titik knot, yakni $K_{1}=7,203$. Dengan demikian, model spline terbaik untuk data AKB dengan persentase persalinan menggunakan tenaga non medis adalah model spline linear dengan 1 titik knot. Selanjutnya dilakukan pengujian signifikansi parameter secara simultan dan individu. Dari hasil pengujian signifikansi secara serentak diperoleh pvalue sebesar $7,734 \times 10^{-11}<\alpha=5 \%$ sehingga dapat disimpulakan bahwa paling sedikit ada satu parameter model yang signifikan. Pengujian signifikansi secara individu dapat dilihat pada Tabel 7.

Tabel 7 Nilai thitung dan P-value untuk Model Spline Univariabel $\left(\mathrm{X}_{3}\right)$

\begin{tabular}{|c|c|c|c|}
\hline No & Parameter & thitung $_{1}$ & P-value \\
\hline 1 & $\hat{\beta}_{0}$ & 17,704 & $2 \times 10-16^{*}$ \\
\hline 2 & $\hat{\beta}_{1}$ & 8,149 & $1,34 \times 10-9^{*}$ \\
\hline 3 & $\lambda_{1}\left(X_{3}-K_{1}\right)$ & $-5,922$ & $9,77 \times 10-7^{*}$ \\
\hline
\end{tabular}
*Signifikan pada $\alpha=5 \%$.
$*_{\text {tabel }}=2,0301$.

Dengan $t_{t a b e l}$ sebesar 2,0301 dan menggunakan tingkat signifikansi 5\% diperoleh hasil bahwa semua parameter dalam model signifikan. Selanjutnya dilakukan uji asumsi residual identik, independen dan normalitas. Model spline ini diberikan oleh persamaan :

$$
\begin{aligned}
\hat{f}\left(x_{3}\right) & =21,6480+3,6904 x_{3}-3,88\left(x_{3}-7,203\right)_{+} \\
& =\left\{\begin{array}{cc}
21,6480+3,6904 x_{3}, & x_{3}<7,203 \\
49,59564-0,1896 x_{3}, & x_{3} \geq 7,203
\end{array}\right.
\end{aligned}
$$

Tabel 8 berikut menyajikan nilai GCV dari berbagai model spline linear dan berbagai titik knot pada data AKB dengan persentase penduduk miskin. nilai titik knot optimal yang dilihat dari GCV minimum titik knot pada model spline linear dengan dua titik knot, yakni $K_{1}=20,066$ dan $K_{2}=$ 20,769. Dengan demikian, model spline terbaik untuk data AKB dengan persentase penduduk miskin adalah model spline linear dengan 2 titik knot. Selanjutnya dilakukan pengujian signifikansi parameter secara simultan dan individu. Dari hasil pengujian signifikansi secara serentak diperoleh p- www.unipasby.ac.id

value sebesar $6,853 \times 10^{-5}<\alpha=5 \%$ sehingga dapat disimpulakan bahwa paling sedikit ada satu parameter model yang tidak sama dengan nol.

Tabel 8 Nilai GCV Minimum dari 3 Model Spline Linear $\left(\mathrm{X}_{4}\right)$

\begin{tabular}{|c|c|c|c|c|}
\hline \multirow{2}{*}{$\begin{array}{c}\text { Jumlah } \\
\text { Knot }\end{array}$} & \multicolumn{3}{|c|}{ Letak Titik Knot } & nilai \\
\cline { 2 - 4 } & 1 & 2 & 3 & $\begin{array}{c}\text { GCV (K) } \\
\text { Optimal }\end{array}$ \\
\hline 1 & 16,551 & - & - & 86,94190 \\
\hline 2 & $\mathbf{2 0 , 0 6 6}$ & $\mathbf{2 0 , 7 6 9}$ & - & $\mathbf{8 3 , 2 9 0 6 5}$ \\
\hline 3 & 15,848 & 16,551 & 17,254 & 85,05771 \\
\hline
\end{tabular}

Sedangkan pengujian signifikansi secara individu dapat dilihat pada Tabel 9 berikut.

Tabel 9 Nilai thitung dan P-value untuk Model Spline Univariabel $\left(\mathrm{X}_{4}\right)$

\begin{tabular}{|c|c|c|c|}
\hline No & Parameter & thitung $_{1}$ & P-value \\
\hline 1 & $\hat{\beta}_{0}$ & 3,235 & $0.00271^{*}$ \\
\hline 2 & $\hat{\beta}_{1}$ & 2,886 & $0.00673^{*}$ \\
\hline 3 & $\lambda_{1}\left(X_{4}-K_{1}\right)$ & 2,098 & $0.04339^{*}$ \\
\hline 4 & $\lambda_{2}\left(X_{4}-K_{2}\right)$ & $-2,118$ & $0.04154^{*}$ \\
\hline
\end{tabular}
*Signifikan pada $\alpha=5 \%$.
*tabel $=2,0322$.

Dengan $t_{\text {tabel }}$ sebesar 2,0322 dan menggunakan tingkat signifikansi 5\% diperoleh hasil bahwa semua parameter dalam model signifikan. Selanjutnya dilakukan uji asumsi residual identik, independen dan normalitas. Model spline ini diberikan oleh persamaan :

$$
\begin{gathered}
\hat{f}\left(x_{4}\right)=14,5639+1,1029 x_{4}+25,6323\left(x_{4}-20,066\right)_{+} \\
-29,2368\left(x_{4}-20,769\right)_{+} \\
=\left\{\begin{array}{c}
14,5639+1,1029 x_{4}, x_{4}<20,066 \\
-499,7738+26,7352 x_{4}, 20,066 \leq x_{4}<20,769 \\
107,4452-2,5016 x_{4}, x_{4} \geq 20,769
\end{array}\right.
\end{gathered}
$$

\subsection{Model Spline Multivariabel}

Dari keempat variabel independen tersebut kemudian dicobakan beberapa model spline linear dengan satu titik knot, dua titik knot dan tiga titik knot berdasarakan GCV minimum dari tiap variabel independen. Dari model-model spline linear multivariabel satu titik knot, dua titik knot dan tiga titik knot perlu dipilih model terbaik. Model spline terbaik diperoleh dari nilai GCV minimum sebesar 34,11737 untuk model spline linear multivariabel dengan satu titik knot. Selanjutnya pada Tabel disajikan titik knot optimal yang bersesuaian dengan nilai GCV minimum dengan model spline linear satu titik knot. 
J Statistika Vol. 11, No. 2,(2018), Hal. 9-16

Tabel 10 Nilai GCV Model Spline Linear Multivariabel Satu Titik Knot

\begin{tabular}{|c|c|c|c|c|c|}
\hline \multirow{2}{*}{ No } & \multicolumn{4}{|c|}{ Titik Knot } & \multirow{2}{*}{ GCV } \\
\cline { 2 - 5 } & $\mathrm{X}_{1}$ & $\mathrm{X}_{2}$ & $\mathrm{X}_{3}$ & $\mathrm{X}_{4}$ & \\
\hline 1 & 10,4080 & 21,0103 & 3,0870 & 15,8480 & 45,25501 \\
\hline 2 & 11,1420 & 22,6270 & 4,1160 & 16,5510 & 45,12674 \\
\hline 3 & 11,8760 & 33,9439 & 5,1450 & 17,2540 & 39,04648 \\
\hline 4 & 22,1520 & 35,5606 & 6,1740 & 20,0600 & 36,45121 \\
\hline 5 & $\mathbf{2 2 , 8 8 6 0}$ & $\mathbf{3 7 , 1 7 7 3}$ & $\mathbf{7 , 2 0 3 0}$ & $\mathbf{2 0 , 7 6 9 0}$ & $\mathbf{3 4 , 1 1 7 3 7}$ \\
\hline
\end{tabular}

Tabel 10 menjelaskan bahwa nilai GCV minimum sebesar 34,11737 berada pada titik-titik knot $K_{1}=$ $22,886, K_{2}=37,1773, K_{3}=7,203$, dan $K_{4}=20,769$. Selanjutnya Estimasi model spline ditunjukkan pada Tabel 11.

Tabel 11 Estimasi Model Spline Linear Multivariabel Satu Titik Knot

\begin{tabular}{|c|r|}
\hline Parameter & Estimasi \\
\hline$\hat{\beta}_{0}$ & 11,3404 \\
\hline$\hat{\beta}_{1}$ & 1,1772 \\
\hline$\lambda_{1}\left(X_{1}-K_{1}\right)$ & $-6,0560$ \\
\hline$\hat{\beta}_{2}$ & 0,0527 \\
\hline$\lambda_{2}\left(X_{2}-K_{2}\right)$ & $-1,2742$ \\
\hline$\hat{\beta}_{3}$ & 1,5669 \\
\hline$\lambda_{3}\left(X_{3}-K_{3}\right)$ & $-1,1516$ \\
\hline$\hat{\beta}_{4}$ & 0,3248 \\
\hline$\lambda_{4}\left(X_{4}-K_{4}\right)$ & 0,4046 \\
\hline
\end{tabular}

Berdasarkan Tabel 11 diperoleh model spline linear multivariabel dengan satu titik knot untuk keempat variabel independen sebagai berikut :

$$
\begin{aligned}
\hat{f}(x)=11,3404+1,1772 x_{1}-6,056\left(x_{1}-\right. \\
22,886)_{+}+0,0527 x_{2}-1,2742\left(x_{2}-\right. \\
37,1773)_{+}+1,5669 x_{3}-1,1516\left(x_{3}-\right. \\
7,203)_{+}+0,3248 x_{4}+0,4046\left(x_{4}-\right. \\
20,769)_{+}
\end{aligned}
$$

Dari model spline linear multivariabel dengan 1 titik knot diperoleh pula nilai koefisien determinasi sebesar $84,21 \%$. Hal ini berarti dari keempat variabel independen mampu menerangkan sebesar 84,21\% terhadap Angka Kematian Bayi Di Jawa Timur Tahun 2015. Sedangkan sisanya sebesar $15,79 \%$ dijelaskan oleh variabel lain yang tidak masuk ke dalam model.

\section{a. Uji Signifikansi Parameter}

Pengujian signifikansi parameter model regresi terdiri dari 2, yaitu uji simultan dan uji individu. Uji simultan pada dasarnya menunjukkan apakah semua www.unipasby.ac.id

variabel independen yang dimasukkan dalam model mempunyai pengaruh secara bersama-sama terhadap variabel dependen AKB.

Hipotesis yang diuji adalah :

$\mathrm{H}_{0}: \widehat{\beta}_{1}=\widehat{\beta}_{2}=\ldots=\widehat{\beta}_{8}=0$.

$\mathrm{H}_{0}$ : paling sedikit ada satu $\widehat{\beta}_{j} \neq 0, j=1,2, \ldots, 8$.

Digunakan tingkat signifikansi $5 \%$.

Dari hasil perhitungan uji serentak pada model spline linear multivariabel (empat variabel independen) dengan 1 titik knot diperoleh nilai $F_{\text {hitung }}$ sebesar 19,34 dan p-value sebesar 1,097 x 10${ }^{9}$ yang lebih kecil dari $\alpha=5 \%$ yang artinya tolak $\mathrm{H}_{0}$. Dengan demikian dapat disimpulkan bahwa paling sedikit ada satu parameter model yang tidak sama dengan nol. Selanjutnya dilakukan pengujian secara parsial dengan hipotesis sebagai berikut :

$\mathrm{H}_{0}=\hat{\beta}_{\mathrm{j}}=0, \mathrm{j}=1,2, \ldots 8 \quad\left(\right.$ Variabel $\mathrm{X}_{\mathrm{j}}$ tidak berpengaruh terhadap model)

$\mathrm{H}_{1}=\hat{\beta}_{\mathrm{j}} \neq 0, \mathrm{j}=1,2, \ldots 8$ (Variabel $\mathrm{X}_{\mathrm{j}}$ berpengaruh terhadap model)

\begin{tabular}{|c|c|c|}
\hline Parameter & $t_{\text {hitung }}$ & P-value \\
\hline$\hat{\beta}_{1}$ & 2,5200 & $0,017500 *$ \\
\hline$\lambda_{1}\left(X_{1}-K_{1}\right)$ & $-0,6970$ & 0,491546 \\
\hline$\hat{\beta}_{2}$ & 0,2830 & 0,779518 \\
\hline$\lambda_{2}\left(X_{2}-K_{2}\right)$ & $-2,2770$ & $0,030335^{*}$ \\
\hline$\hat{\beta}_{3}$ & 1,8120 & 0,080330 \\
\hline$\lambda_{3}\left(X_{3}-K_{3}\right)$ & $-0,7480$ & 0,460780 \\
\hline$\hat{\beta}_{4}$ & 0,9860 & 0,332324 \\
\hline$\lambda_{4}\left(X_{4}-K_{4}\right)$ & 0,1200 & 0,905296 \\
\hline
\end{tabular}

Nilai $t_{\text {hitung }}$ dan P-value untuk uji parsial disajikan dalam Tabel 12.

Tabel 12 Nilai thitung dan P-Value Untuk Model Spline Multivariabel

Dengan menggunakan $t_{\text {tabel }}$ sebesar 2,0452 dan tingkat signifikansi $5 \%$ diperoleh parameterparameter yang signifikan adalah parameter $\beta_{1}$ dan $\lambda_{2}\left(X_{2}-K_{2}\right)$. Sedangkan pada variabel $X_{3}$ dan $X_{4}$ tidak terdapat parameter model yang signifikan. Jadi dapat disimpulkan dengan tingkat signifikansi 5\% bahwa variabel $\mathrm{X}_{1}$ (persentase perempuan yang usia perkawinan pertama kurang dari 17 tahun) dan $\mathrm{X}_{2}$ (persentase wanita yang tidak pernah sekolah/tidak tamat SD) berpengaruh nyata terhadap Angka Kematian Bayi di Jawa Timur Tahun 2015. Sedangkan variabel $\mathrm{X}_{3}$ (persentase persalinan oleh tenaga non medis) dan $\mathrm{X}_{4}$ (persentase penduduk 
miskin) tidak berpengaruh nyata terhadap Angka Kematian Bayi di Jawa Timur Tahun 2015.

Dengan demikian model spline multivariabel dengan satu titik knot untuk keempat variabel independen yang mempengaruhi AKB tahun 2015 di Jawa Timur adalah sebagai berikut :

$$
\begin{gathered}
\hat{f}(x)=11,3404+1,1772 x_{1}-6,056\left(x_{1}-\right. \\
22,886)_{+}+0,0527 x_{2}-1,2742\left(x_{2}-\right. \\
37,1773)_{+}+1,5669 x_{3}-1,1516\left(x_{3}-\right. \\
7,203)_{+}+0,3248 x_{4}+0,4046\left(x_{4}-\right. \\
20,769)_{+}
\end{gathered}
$$

Interpretasi dari persamaan model diatas adalah sebagai berikut : apabila persentase perempuan yang usia perkawinan pertama kurang dari 17 tahun < $22,886 \%$, ketika variabel independen ini naik sebesar 1\%, maka Angka Kematian Bayi di Jawa Timur naik sebesar 1,1772. Apabila persentase perempuan yang usia perkawinan pertama kurang dari 17 tahun lebih besar atau sama dengan $22,886 \%$, ketika variabel independen ini naik sebesar 1\%, maka Angka Kematian Bayi akan turun sebesar 4,879. Sedangkan apabila persentase wanita yang tidak pernah sekolah/tidak tamat SD < $37,1773 \%$, ketika variabel independen ini naik sebesar 1\%, maka Angka Kematian Bayi di Jawa Timur naik sebesar 0,0527. Apabila persentase wanita yang tidak pernah sekolah/tidak tamat SD lebih besar atau sama dengan 37,1773\%, ketika variabel independen ini naik sebesar $1 \%$, maka Angka Kematian Bayi akan turun sebesar 1,2215.

\section{b. Pengujian Asumsi Model Spline Multi- variabel}

Selanjutnya dilakukan pengujian asumsi dari model spline linear multivariabel dengan 1 titik knot. Pengujian asumsi residual yang digunakan antara lain : uji normalitas, uji independen dan uji identik. Pengujian asumsi model spline linear multivariabel 3 titik knot disajikan pada Tabel 13.

Tabel 13 Pengujian Asumsi Model Spline Linear Multivariabel

\begin{tabular}{|l|c|c|c|}
\hline Pengujian & P-value & Keputusan & Kesimpulan \\
\hline Identik & 0,1747 & $\begin{array}{c}\text { Gagal Tolak } \\
\mathrm{H}_{0}\end{array}$ & Asumsi Terpenuhi \\
\hline Independen & 0,8500 & $\begin{array}{c}\text { Gagal Tolak } \\
\mathrm{H}_{0}\end{array}$ & Asumsi Terpenuhi \\
\hline Normalitas & 0,5394 & $\begin{array}{c}\text { Gagal Tolak } \\
\mathrm{H}_{0}\end{array}$ & Asumsi Terpenuhi \\
\hline
\end{tabular}

Berdasarkan Tabel 13 diperoleh hasil pengujian identik, independen dan normalitas. Pengujian asumsi homogen atau uji identik digunakan Uji Breusch Pagan dengan diperoleh $P$-value sebesar 0,1747 yang lebih besar dari $\alpha=5 \%$, yang berarti gagal tolak $\mathrm{H}_{0}$. Dengan demikian, dapat disimpulkan bahwa tidak terdapat heterokesdasitas atau dengan kata lain varians residual identik. Uji independen dilakukan dengan menggunakan uji Durbin-Watson, dengan diperoleh p-value sebesar 0,85 yang berarti gagal tolak $\mathrm{H}_{0}$. Dengan demikian dapat disimpulkan bahwa model spline linear multivariabel dengan 1 titik knot memenuhi asumsi independen. Pengujian normalitas digunakan uji Kolmogorov-Smirnov diperoleh P-value sebesar 0,5394 yang lebih besar dari $\alpha=5 \%$ yang berarti gagal tolak $\mathrm{H}_{0}$. Sehingga dapat disimpulkan bahwa residual dari model spline linear multivariabel dengan 1 titik knot berdistribusi normal.

\section{KESIMPULAN DAN SARAN}

Berdasarkan hasil analisis, berikut kesimpulan yang diperoleh dari analisis univariat dan multivariat.

1. Model spline linear univariabel sebagai berikut :

a. Apabila persentase perempuan yang usia perkawinan pertama kurang dari 17 tahun < $11,142 \%$, ketika variabel independen ini naik sebesar 1\%, maka Angka Kematian Bayi di Jawa Timur naik sebesar 1,472. Apabila persentase perempuan yang usia perkawinan pertama kurang dari 17 tahun lebih besar atau sama dengan 11,876\%, ketika variabel independen ini naik sebesar 1\%, maka Angka Kematian Bayi akan naik sebesar 0,356.

b. Apabila persentase wanita yang tidak pernah sekolah/tidak tamat SD $<35,5606 \%$, ketika variabel independen ini naik sebesar $1 \%$, maka Angka Kematian Bayi di Jawa Timur naik sebesar 0,4298.

c. Apabila persentase persalinan oleh tenaga non medis $<7,203 \%$, ketika variabel independen ini naik sebesar 1\%, maka Angka Kematian Bayi di Jawa Timur naik sebesar 3,6904.

d. Apabila persentase penduduk miskin < $20,066 \%$, ketika variabel independen ini naik sebesar 1\%, maka Angka Kematian Bayi di Jawa Timur naik sebesar 1,1029.

2. Pemodelan regresi spline pada studi kasus faktor-faktor yang mempengaruhi Angka Kematian Bayi di Jawa Timur tahun 2015 diperoleh model spline linear multivariabel sebagai berikut :

$$
\begin{aligned}
\hat{f}(x) & =11,3404+1,1772 x_{1}-6,056\left(x_{1}-\right. \\
22,886)_{+}+0,0527 x_{2}- & 1,2742\left(x_{2}-\right. \\
37,1773)_{+}+1,5669 x_{3}- & 1,1516\left(x_{3}-\right. \\
& 7,203)_{+}+0,3248 x_{4}+0,4046\left(x_{4}-\right. \\
& 20,769)_{+}
\end{aligned}
$$

Variabel yang berpengaruh signifikan tehadap angka kematian bayi di Jawa Timur tahun 2015 adalah : persentase perempuan yang usia 
perkawinan pertama kurang dari 17 tahun dan persentase wanita yang tidak pernah sekolah/tidak tamat SD. Interpretasi dari persamaan model diatas sebagai berikut apabila persentase perempuan yang usia perkawinan pertama kurang dari 17 tahun < $22,886 \%$, ketika variabel independen ini naik sebesar 1\%, maka Angka Kematian Bayi di Jawa Timur naik sebesar 1,1772. Apabila persentase perempuan yang usia perkawinan pertama kurang dari 17 tahun lebih besar atau sama dengan 22,886\%, ketika variabel independen ini naik sebesar 1\%, maka Angka Kematian Bayi akan turun sebesar 4,879. Sedangkan apabila persentase wanita yang tidak pernah sekolah/tidak tamat SD < $37,1773 \%$, ketika variabel independen ini naik sebesar 1\%, maka Angka Kematian Bayi di Jawa Timur naik sebesar 0,0527. Apabila persentase wanita yang tidak pernah sekolah/tidak tamat SD lebih besar atau sama dengan $37,1773 \%$, ketika variabel independen ini naik sebesar 1\%, maka Angka Kematian Bayi akan turun sebesar 1,2215.

Untuk penelitian selanjutnya saran yang dapat penulis sampaikan adalah melakukan perbandingan model spline pada penelitian ini dengan model spline kuadratik dan kubik dengan orde pada setiap variabelnya ditambahkan, misalnya sampai 5 (lima) titik knot. Selain itu, apabila ingin menggunakan data penelitian ini, disarankan untuk menambah indikator lain yang belum dimasukkan dalam model. Seperti pada variabel independen, indikator yang ditambahkan adalah jumlah bayi gizi buruk, berat bayi lahir rendah, persentase bayi yang tidak diberi ASI, persentase Ibu hamil yang tidak melakukan kunjungan kehamilan dan persentase Ibu hamil yang mendapatkan tablet $\mathrm{Fe} 3$.

\section{DAFTAR PUSTAKA}

Badan Pusat Statistik Provinsi Jawa Timur. 2016. Laporan Eksekutif Kesehatan Provinsi Jawa Timur [Internet]. Tersedia pada https://jatim.bps.go.id/publication/download. htm. Diakses tanggal 20 Januari 2018.

Badan Pusat Statistik. 2004. Survei Demografi dan Kesehatan Indonesia tahun 2002-2003. BPS: Jakarta.

Euba nk, R, L.. 1999. Nonparametric Regression and Spline Smoothing. $2^{\text {nd }} e d$. Marcel Dekker: New York.
Kementerian Kesehatan RI. 2014. Pusat Data dan Informasi [Internet]. Tersedia pada http://www.depkes.go.id/resources/downloa d/pusdatin/infodatin/infodatin-ibu.pdf.

Diakses tanggal 24 Januari 2018.

Mubarak, R., dan Budiantara, I N.. 2012. Analisis Regresi Spline Multivariabel untuk Pemodelan Kematian Penderita Demam Berdarah Dengue (DBD) di Jawa Timur, JURNAL SAINS DAN SENI ITS Vol. 1, No. 1, (Sept. 2012) ISSN: 2301-928X, Institut Teknologi Sepuluh November: Surabaya.

Pudiastuti, Ratna Dewi. 2011. Waspada Penyakit Pada Anak. PT. Indeks: Jakarta. 